\title{
Specialized Programs in Drama: a gateway to self and art in society
}

Francine Chaîné Université Laval - Québec, Canada

Mariette Théberge Université d'Ottawa - Ontario, Canada

ABSTRACT - Specialized Programs in Drama: a gateway to self and art in society - This article explores the unique contexts of two specialized drama education programs that offer adolescents from twelve to eighteen years of age the chance to create, perform, and appreciate works of art. Describing these two contexts helps to clarify how their respective missions support these young people in affirming their identities and constructing their world views. The drama program offered at La Maison Jaune, located in Quebec City, Quebec, allows students to explore the meaning of their experience of the creative process. The Centre d'Excellence Artistique De La Salle in Ottawa, Ontario, places drama training in a societal context where the educational practices contribute to artistic renewal and to the collective imagination.

Keywords: Drama. Adolescents. Specialized Programs. Identity. Artistic Experiment.

RÉSUMÉ-Programmes Spécialisés en Théâtre: une voie d'accès à soi et à l'art dans la société - Cet article explore la singularité de deux contextes de formation spécialisée en art dramatique qui ont comme mission d'offrir à des adolescents de 12 à 18 ans des expériences de création, d'interprétation et de réception d'œuvres d'art. La description de ces contextes contribue à saisir leur mission respective constituant pour ces jeunes un point d'ancrage tant dans leur affirmation identitaire que dans la construction de leur vision du monde. D'une part, la formation offerte à La Maison Jaune, située dans la ville de Québec, dans la province de Québec, permet d'explorer le sens d'expériences de mise en œuvre du processus de création. D'autre part, le Centre d'Excellence Artistique De La Salle d'Ottawa en Ontario situe cette formation dans un contexte sociétal où les pratiques éducationnelles confèrent un apport à la relève artistique et à l'imaginaire collectif.

Mots-clés: Théâtre. Adolescents. Programmes Spécialisés. Identité. Expérience Artistique.

RESUMO - Programas Especializados em Teatro: um caminho para si e para a arte na sociedade - Este artigo explora os contextos originais de dois programas especializados em educação em teatro que oferecem a adolescentes entre doze e dezoito anos de idade a possibilidade de criar, desenvolver e compreender trabalhos de arte. A descrição desses dois contextos ajuda a esclarecer como suas respectivas missões apoiam esses jovens na afirmação de suas identidades e na construção de sua visão de mundo. O programa de teatro oferecido na Maison Jaune, situada na cidade de Quebec, província de Quebec, permite que os estudantes explorem o sentido de sua experiência no processo criativo. O Centre d'Excellence Artistique De La Salle, em Ottawa, Ontário, coloca a formaçáa em teatro em um contexto social em que as práticas educacionais contribuam para a renovação artística e a imaginação coletiva.

Palavras-chave: Teatro. Adolescentes. Programas Especializados. Identidade. Experiência Artística. 
This article explores two drama programs training contexts, each with a specific status: La Maison Jaune [The Yellow House] in Quebec City, in the province of Quebec, and the Centre d'Excellence Artistique de La Salle [La Salle Centre for Artistic Excellence], located in downtown Ottawa, Ontario. Both offer drama training to adolescents between the ages of twelve and eighteen, throughout their five or six years of secondary school. The programs provide meaningful drama education by connecting the adolescents enrolled in the programs with professional theatre artists and by offering them the opportunity to learn about this art form. Both programs thereby constitute privileged forums for training and identity affirmation and inspire the student to find gateways to self and art in society.

By contextualizing the experiences adolescents, artist-teachers, organizers, board members, and parents have in these drama programs, we can see how theater impacts the lives of those who engage with it (Dewey, 2005). Theater changes our attitude to risk, to expressing opinions, and to saying what we want and what we feel. These educational experiments also provided us an occasion to participate as researchers. We became part of the conversation about these programs in order both to better understand them and to promote their goals. This article is an opportunity to further consider these two remarkable programs, keeping in mind that adolescents can be the best teachers, and taking into account the social contexts that characterize them.

Given that this research aims to highlight the richness and diversity of the experiences created at La Maison Jaune and the Centre d'Excellence Artistique de La Salle, in this article we will first describe each of these two contexts before outlining our conceptual framework, which is supported by two key concepts in art education: experience and identity. Next, we will articulate how the multiple case study methodological framework allows the researcher "[...] to identify reoccurring phenomena in a given number of situations" (Mucchielli, 2009, p. 93). In conclusion, we will show how the practice of creating, performing, and appreciating artworks offers gateways to art through meaningful experiences that encourage commitment to oneself, and to society. 


\section{Specialized Drama Programs in Two Contexts}

In this study, we examine two specialized drama programs, one in Quebec and one in Ontario - two Canadian provinces with very different linguistic demographics. The majority of the population of Quebec is francophone, and more specifically, in Quebec City, 95\% of the population was francophone in 2001 (Leclerc, 2011). Ontario has a francophone population of $4.8 \%$, of which $19.9 \%$ reside in Ottawa $^{1}$ (Conseil de Planification Sociale d'Ottawa, 2010; Office Affaires Francophones de l'Ontario, 2006). Despite this demographic distinction, we see that the syllabi of both programs are very similar: both teach by creating, performing, and appreciating art with their students, and both uphold a mission to offer excellent training led by professional theatre artists. In the next section, we will present their respective characteristics.

\section{La Maison Jaune [The Yellow House]}

La Maison Jaune houses a drama program that is but one component of the much larger Arts-Sports-Etudes [Art-Sports-Study] program at Cardinal-Roy public secondary school, which has offered high quality sports and arts programs for the past twenty five years. This program is recognized by the Quebec Ministry of Education, Recreation and Sport and administered by sports federations and affiliated arts organizations (École Secondaire Cardinal-Roy, 2014). La Maison Jaune has been in charge of the drama program since the late 1990s. Students enrolled in specialized programs such as the drama program take subjects like French and Mathematics at the school in the morning, and then move to the site of their arts or sports program in the afternoon. This schedule allows for a balance between academic and other studies.

The drama program aligns with the departmental targets of the Quebec Ministry of Education, Recreation and Sport (Gouvernement du Québec, 2006) and is made up of four areas of study (playwriting, performing, directing, and appreciating theatre) with a focus on creating, acting in, and directing plays. Training in dramatic arts develops not only psychomotor, emotional, social, intellectual, and cultural skills, but also develops three additional abilities: the ability to create, to perform, and to appreciate dramatic works of art. Developing these abilities is conducive to building the student's 
identity in that he uses his body and his voice, the two fundamental elements of the dramatic language (Gouvernement du Québec, 2006, p. 379-380).

The aim of La Maison Jaune's drama program is “[...] to foster success in academic subjects, the pursuit of artistic training led by professionals, the development in the students of self-confidence and the spirit of initiative, and the desire to excel" (École Secondaire Cardinal-Roy, 2014, n.p.). This five-year program is offered from the first through the fifth year of secondary school. Adolescents aged twelve to seventeen in good academic standing can apply to the program, and must pass an audition. Each year they are evaluated to assess their ability to continue in the program. Eligible students can join at any point, though many students take drama throughout their secondary school education.

The program offered by La Maison Jaune applies both individual and group approaches, while focusing on four areas of learning: improvisation, performance, voice and diction, and expressive movement. A maximum of twenty students are enrolled. This is a good number given the many art programs offered at the CardinalRoy secondary school: Drama, Visual Arts, Vocal Music, Cinema, Circus, Dance, and Music, in addition to all the sports-related programs. The twenty adolescents enrolled in the drama program are placed in two groups of ten students and take courses with different artist-teachers, all professional artists who studied at one of three theatre schools in Quebec ${ }^{2}$. The artist-teachers guide their students in the process of creating and performing theatre (Gouvernement du Québec, 2006, p. 382). With this project-based approach, one of the teachers accompanies each group as they create and perform a piece of theatre that is presented to the public at the end of the school year. The other drama teachers adjust the content of their courses to align with the group's project, and in this way the movement and voice work supports the creative process developed over the course of the school year. The teachers' commitment to each group's project creates a dynamic and lively space that could be described by Buber, "To take action is to create, to invent is to find, to give form is to discover" (1969, p. 29). 
The Centre d'Excellence Artistique De La Salle [De La Salle Centre for Artistic Excellence]

Founded in 1983, the Centre d'Excellence Artistique De La Salle of the Conseil des écoles publiques de l'Est de l'Ontario (CEPEO) [Public School Board of Eastern Ontario], is located in downtown Ottawa (École Secondaire Publique De La Salle, 2014). The aim of this program, for adolescents from twelve to seventeen years of age, is "[...] to give solid pre-professional training to students who are considering a professional career as an artist" (Hoyi, 2013, p. 8). To achieve this goal, eight different concentrations are offered: Visual and Media Arts, Contemporary Dance, Writing and Literary Creation, Instrumental Music (strings), Instrumental Music (wind and percussion), Vocal Music, Drama, and Film and Television. "With a student body of 1,200 students from 72 different countries, this school is an important cornerstone of arts education for the francophone people of Ontario, and also welcomes students from throughout the province and from other countries. The great cultural diversity of the school's population engenders the open-mindedness so necessary to the future artist" (Hoyi, 2013, p. 8).

This is a six-year arts program. In the first two years, students aged 12 to 14 explore four artistic disciplines in order to clarify their interests, discover their aptitudes, and choose an artistic discipline. Next, based on the teachers' recommendation, the student must take an entrance exam and audition to be accepted into the artistic concentration of his choice (Hoyi, 2013, p. 8). Successful candidates then take part in a four-year specialized program that includes a seventy-five-minute class each day and additional time, which for the drama section includes rehearsals, a yearly tour to neighbouring elementary schools, and a province wide tour at the end of the school year.

While it follows the prerogatives established by the Ministère de l'Éducation de l'Ontario [Ontario Ministry of Education] (2009, 2010a, 2010b), the drama program focuses specifically on "[...] the development of the actor," and integrates an in-depth study of "[...] the different components of the language of theatre: voice, gesture, and movement". Over the course of the program, the student "[...] becomes familiar with the performance of roles from both the French Canadian and international repertoire". He is also introduced "[...]

Francine Châ̂né; Mariette Théberge - Specialized Programs in Drama: a gateway to self and art in society Rev. Bras. Estud. Presença, Porto Alegre, v. 5, n. 2, p. 356-375, May/Aug. 2015. Available at: <http://www.seer.ufrgs.br/presenca> 
to the world of playwriting and drama criticism, through the study of theatre history," and attends several theatre productions each year (École Secondaire Publique De La Salle, 2014, n.p.).

The teachers are theatre professionals trained in both theatre arts and education ${ }^{3}$. They are thus well suited to provide this specialized training and to assess their students' progress in their courses (which count towards the requirements for high school graduation). In addition, these artist-teachers are strongly encouraged to pursue their artistic career by participating in professional theatre productions, and thus stay up to date with developments in their field. Other professional artists replace them when they are in rehearsals, and this in no way affects their salary or their job security. This approach aligns with the Centre's goal of employing a staff of teachers with careers in both theatre and education, which benefits students destined for careers in the arts.

In 2013, the Centre d'Excellence Artistique De La Salle attained the status of École Communautaire Citoyenne (Citizen and Community-based School). With this particular orientation this school continues to be:

A place for learning, socialization and construction of self-identity, in osmosis with the community it serves. It contributes to the success of the students, to the flourishing of their community and to the fostering of a global awareness. With these objectives, it engages and mobilizes the students, the teaching staff, the parents, and the community partners (Table Nationale sur l'Éducation, 2012, p. 9).

The Centre d'Excellence Artistique De La Salle is a beacon of pre-professional training for artists that reinforces the ties between school and community and helps raise awareness of the role school plays in society by offering excellent artistic training and by fostering the engagement of all its partners (Fédération Nationale des Conseils Scolaires Francophones, 2011).

\section{Conceptual Framework}

In this study of these two specialized drama programs for adolescents aged twelve to eighteen, two concepts - experience and identity - guide the analysis of the interviews, observations, and documents. These two complimentary concepts combine to provide 
a two-dimensional perspective on how these specialized programs offer support to the students on personal, institutional, and societal levels. The definitions in the following sections will demonstrate that these programs offer rich experiences that encourage the young people to affirm themselves and thus construct their self-identity.

\section{The Concept of Experience}

The concept of experience comes from the word experiri, to try out, which refers to Dewey's classic Learning by Doing (Ardenne; Beausse; Goumarre, 1999, p. 11). For Dewey, "[...] an experience arouses curiosity, strengthens initiative, and sets up desires and purposes that are sufficiently intense to carry a person over dead places in the future" (1997, p. 38). He adds that "[e]xperience does not go on simply inside a person, [but] it does go on there, for it influences the formation of attitudes of desire and purpose" (1997, p. 39). In the context of drama, experience is collective, and "[...] children and young people are changed by that which is important, rather than the form of the drama work itself" (Neelands, 2009, p. 181).

In the context of the programs offered at La Maison Jaune and the Centre d'Excellence Artistique De La Salle, the student has experiences in that he engages in the process of creation, performance, and appreciation of works of art. This process provides a privileged gateway to the self by provoking self-awareness. It raises the question of the student's interests, behaviours, goals, and relationships, by means of acting the parts of characters whose singularity must be expressed. This exploration takes place as much in works created or improvised by the group as in the performance of a contemporary or classic scripted play. Through the program, the adolescent discovers both himself and the theatre. By the very nature of this practice, he becomes part of a community in which he is able to question himself and to grow. Experience actively contributes to his evolution:

Work in the arts is not only a way of creating performances and products; it is a way of creating our lives and expanding our consciousness, shaping our dispositions, satisfying our quest for meaning, establishing contact with others, and sharing a culture (Eisner, 2002, p. 3).

The concept of experience "[...] is a reminder of both the concrete and personal meanings that the individual experiences" by 
evoking a more organic and more holistic form of awareness, all is thus in place for "[...] everything from an intimate feeling to a given social situation" (Sévigny, 2003, p. 129). In addition, an experience is part relationship and part interaction, it involves "[...] the interaction of a live creature with its environment" (Dewey, 2005, p. 283). As for the link between an aesthetic experience and daily life, "[...] it is an imaginative experience" (Dewey, 2005, p. 317). The artistic experience offers the possibility "to complete the creation of the object" (Dewey, 2005, p. 59), but without avoiding confronting the unknown. Indeed, when undertaken in a collective context, the process of creation and performance is marked by moments of discovery that can present surprising avenues to explore, whose significance will only be revealed on the stage.

Experience is an integral part of drama training, whether during icebreaker exercises, verbal or physical improvisations, or in the process of directing, performing, or writing monologues or dialogues. It is by drawing on his own experiences that the adolescent learns the language of theatre, while at the same time learning how to collaborate with his peers in the shared goal of producing a work of art. Experience is, in this sense, a concept that is integral to art (Dewey, 2005) and constitutes the basis of the training offered by the two programs we are referring to in this article. It is also closely tied to the concept of identity, because what each brings to the production has to do with the person's experiences, with what he transcends in his writing, in his acting, and in his directing.

\section{The Concept of Identity}

From a general point of view, the concept of identity represents that which makes us unique and allows us to define ourselves as singular individuals. This concept underpins the construction and affirmation of the subject and is distinguished by three core aspects: individual identity, group or collective identity, and cultural identity (Mucchielli, 1986, p. 29). In the context of theatre arts, where artistic activities are executed both individually and collectively, both individual and group identity are called upon. Cultural identity is also present in the practice because it begins from the participant, who draws upon his own culture and on art to build his character. 
In that the concept of identity is less and less shaped by "[...] the backdrop of traditions and ancestral expectations," the exploration of different perspectives that drama programs provide is linked to the more current definition of identity, in which the person is no longer seen as the reflection of the "totality of his culture" (Linton, 1977, p. XIX). Today, whatever the society, identity is more often articulated in terms of rupture and individual choice. Generations but do not necessarily resemble one another. Given the current reality of globalization, the question of identity becomes more complex and includes both a person's sense of existence and on the choices he can make depending on the constraints of the context in which he lives.

According to Mucchielli, identity is based on a series of senses: a sense of one's material being, of unity and coherence, of temporal continuity, of relatedness and difference, of worth, autonomy, confidence, and of existence. "For a group or culture, the sense of one's material being is the awareness, shared by all the members, of the material elements that provide an objective sense of the group's or culture's existence" (1986, p. 48). This sense of one's material being is related to the sense of unity and coherence that provide experiences tied to the sense of worth, autonomy, relatedness, and difference that form the basis for the sense of confidence and of existence.

The self-awareness gained through the experiences that students live during their drama training represents an anchor for these young people as they both affirm their identity and construct their view of the world. Whether in an educational setting or in professional theatre companies, the practice of drama requires the ability to work with others and to dialogue in order to collaborate on a production. Self-affirmation comes gradually through a number of different productions and exchanges. Who am I in this world? What will I do with my life? What is important to me? What sort of relationships do I prefer? Gradually, the adolescent becomes aware of these questions, begins to make sense of them and evolves by experiencing the confrontation of ideas and by exploring the many dimensions of being human. Drama programs include hours of rehearsals, which offer the opportunity to consider whether to be or not to be and to explore one's identity from a wide variety of perspectives.

The exploration of emotions, as well as discussions about different ways of seeing things, can broaden the students' horizons 
and help them both to define, and come to terms with, their own disposition. For students engaged in the process of creating a dramatic work, self-affirmation is essential given the both individual and collective nature of the project. In order to participate in the collective project of creating a work or of performing a scripted play, each participant must make their own unique contribution to the group. Therefore, the two concepts, experience and identity, intersect with ease in the two specialized drama programs explored in our case study.

\section{Methodology}

One of the goals of this research was to establish relationships with educational contexts that demonstrate excellence in drama programs for adolescent twelve to eighteen years of age. In order to highlight the richness and diversity of these programs, in the next section we will outline and clarify the methodologies we used: our approach to research, our data collection strategies, and our mode of analysis.

This research calls for a qualitative/interpretive multiple case study approach that foregrounds the meaning people give to their experiences (Gagnon, 2011; Merriam, 1988; Mucchielli, 2009). As Savoie-Zajc underlines: "Interpretive research aims to better understand the meaning that a person gives to his experience" (2000, p. 172). This approach can also make possible "[...] the study of a person's affect, engagement, and self-investment", as well as "[...] their relationship to the forms, logics, and workings of social thought [...]" (Anadón; Gohier, 2001, p. 30).

Conducted on site, in the participants' natural environment, our research aligns with the four characteristics of a case study as described by Anadón (2006). It is particular because it is focused on the question of singularity. It is descriptive because the presentation of the results is given in a descriptive form. It is heuristic because it provides the possibility of a deeper understanding. It is inductive due to the connections made based on data collected in the field and then interpreted, in part, by induction.

The data was collected in the two contexts according to three principal strategies: individual interviews, observations, and document analysis. 
At La Maison Jaune, we began by individually interviewing one artist-teacher and nine students (seven girls and two boys) enrolled in the drama program. As Poupart and his colleagues underline (Poupart, 1997), the individual interview makes it possible to ascertain the meaning a person according to what he is experiencing and to better understand how that person situates himself within the context in which he is learning. We also observed the process of creation periodically over six months during the production of Aime-moi Pas, Reste! (Ça Fait-tu ton Bonheur?) [Don't Love Me, Stay! Does that Make you Happy?], which allowed us to corroborate the testimonies gathered in the interviews (Chaîné, 2012). In the context of the Centre d'Excellence Artistique De La Salle, data was collected over close to a decade. It included individual interviews with four teachers (three women and one man), eleven students (ten girls and one boy), two parents (one woman, one man), and the artistic director (one woman). Over the years, these interviews focused on what motivates someone to enrol in a specialized art program, as well as on the implementation of the Citizen and Community-based School Project (Théberge, 2007). Each of the thirty to sixty-minute long semi-structured interviews was conducted within the contexts of these two programs. The interviews focused on the achieved teaching and learning, as well as on the creative process implemented during the production of a theatre play. An analysis of documents from each context also contributed to the data analysis. Upon completion of the interviews, of observing, and of document analysis, successive readings of the data both deepened our comprehension and allowed the categories to emerge (Paillé; Mucchielli, 2008, p. 260). Subsequently, we began to dialogue as researchers, a reflective practice (Schön, 1983) through which, by speaking about our respective research experiences, we were able to consider the programs as a whole, as well as how they related to the possibility of self-affirmation. The recourse to triangulating sources that issued from two different contexts and of three main strategies of data collection provided precise results. In addition, our dialogue as researchers brings a level of plausibility to the interpretation of the studied phenomenon, and lends credibility to the analytic process (Fraenkel; Wallen, 2009; Hamel, 1997). 


\section{The Richness of Practices of Creation, Performance, and Reception of Works of Art}

Based on the data analysis, our exchanges with the educational communities, and our dialogue as researchers, we identified three concomitant gateways, two of which are directly in line with the concepts of experience and identity. A third gateway, involving engagement with self, art, and society, is also present in the two drama program contexts.

\section{First Gateway: unique and meaningful experiences}

The two drama programs in this multiple case study are unique. The Centre d'Excellence Artistique De La Salle is the only francophone high school in Ontario that offers specialized art programs in Drama, Music, Dance, and Visuals Arts, and La Maison Jaune is the only specialized drama program located in a cultural centre in the province of Quebec. Each of these programs is unique within their respective contexts. Due to the importance they place on the personal and collective meanings of experiences lived in dramatic art, the students receive basic voice and movement training to help them perform effectively in character. Given the important role of creativity, the adolescent is also encouraged to share his point of view while contributing to the collective creation's co-constructed meaning. In both institutions, the program culminates in a collectively accomplished production, which provides a deeper understanding of the content and a mastery of the form, while demonstrating what the students have learned.

For example, at La Maison Jaune, we observed the advanced students' theatre project based on excerpts from Britannicus Now! (Perreault, 2011) and Les Apatrides (Perreault, 2005), two plays about young people. This project included both performance and creation. The group was invited to improvise in order to discover the relationships between the characters and the relationships between the selected scenes. These improvisations, directly inspired by the adolescents' own culture, added aspects of their personal identities to the project. The teacher thus collaborated directly with the students by listening to them and welcoming their ideas. They were implicated in the project as much more than simply performers. It was an effective way to use the scripts as an opportunity for dialogue 
and co-construction (Freire, 1974) between the student performers and their teacher. The adolescents created the title of the theatre production by combining elements from each of the two plays: Aimemoi Pas, Reste! and Ça Fais-tu ton Bonheur?

Similarly, in the Centre d'Excellence Artistique De La Salle drama program, groups of students in their final year are tasked with creating a theatre production. The students give themselves challenges far greater than what the teachers could have imagined. They work with meaningful themes and challenge their own worldviews against those contained in Huis Clos [No Exit] by Jean-Paul Sartre, Deux Pas vers les Étoiles by Jean-Rock Gaudreau, La Meute by Esther Beauchemin, and Nouds Papillon by Marie-Eve Huot. Rich, dense content attracts their attention and interest in plays like La Montagne Rouge (Sang) by Steve Gagnon, in which the main character must "[...] go the depth of his soul to reveal the abyss of pain" and thus "[...] regain hope" after having exercised "[...] the suicidal demon from his lover" (Moreault, 2010, n.p.). Needless to say, the discussions are intense and the main challenge is to explore all the possibilities while avoiding all unnecessary concessions.

Requiring the integrity and engaged presence of everyone, including both the students and their teachers, these theatre projects meet the adolescents' needs as they take the risk of group work and of having, in a group context, singular experiences that they will remember for the rest of their lives.

\section{Second Gateway: an affirmation of personal, institutional, and societal identity}

This gateway to accessing singular and meaningful experiences naturally offers the chance to affirm one's personal identity as well as the identity of the institution and that of a given society. For example, one of the objectives of the drama program at La Maison Jaune is to support the individual and collective growth of the adolescents. This is why, in the rehearsal stage, the students are invited to take part in the improvisational explorations of each character, without knowing which character they will perform in the production. According to Perrault $(2005,2011)$, this pedagogical approach allows the students to explore different universes and different characters and prevents them from prematurely identifying with one character. 
With this approach, each participant remains open to the whole play and not only his or her character. Observing colleagues perform a character also helps each member of the group to find different ways of approaching the role that they will play. The characters are thus created individually and collectively and belong to the group rather than to one person. Throughout the creative process, everyone helps flesh out the characters in the selected excerpts, thus fostering a spirit of solidarity between the adolescents, who are engaged in a project that they are making their own.

Furthermore, the depth of what the adolescents have to say and their ability to express their commitment is felt well beyond the walls of the school. Their affirmation of their personal identity thus contributes to both institutional and societal affirmation of identity. The student theatre productions are performed at the school and then taken on tour to different regions of the province. Touring these theatre productions, they promote the works of the performed art, the school, and community, as well as the culture in which each of these drama programs plays a part. A case in point: the resounding success of the group from the Centre d'Excellence Artistique De La Salle that mounted the production of Nouds Papillon by MarieEve Huot in 2014. Even though this production was presented in French to an almost exclusively English speaking audience at the Sears Ontario Drama Festival, at the regional level this production won the Cast Award for Excellence, the Adjudicator's Award, and was chosen as Outstanding Production, while at the provincial level, it won the Ensemble Performance Award and the Direction Outstanding Achievement Award (Sears Ontario Drama Festival, 2014).

These honours could be achieved not only because the adolescents engage actively in what they do, but also because the artist-teachers who guide them, their parents, and the community support them in their work. In both of these social contexts, the drama program is part of a tradition in which the community members and professional artists help to establish programs that nurture the next generation of artists. It is the commitment of both the artistic community and educators, in concert with the decisionmaking bodies at the community and political-ministerial levels that provide a forum in which these adolescents can realize their dreams. From this statement emerges the third path that we identified: that of an engagement with self, with art, and with society. 


\section{Third Gateway: engagement with self, with art, and with society}

Experience and the affirmation of identity could not take place without personal, institutional, and societal engagement. As we have just mentioned, if these specialized theatre programs are established in the schools, it is because the community felt a need to engage with dramatic art. Be it at La Maison Jaune or at the Centre d'Excellence Artistique De La Salle, taking part in the theatre project over several months (from three to nine months) requires a commitment to oneself and to others, and also to the process of creation and performance. Depending on the needs of the production, the work can be accomplished in sequence. It includes spatial work (the blocking, the layout of the space, the characters' entrances and exits), vocal work (voice coaching, projection, intonation, variation of emotion, chorus), and physical work (the characters' posture and hand gestures, group scenes, rhythm). This work requires a commitment to appropriating and to embodying content.

This engagement with self and with art is impossible without taking risks, without an intersubjectivity in which "[...] grounding oneself in the need for identity goes hand and hand with the desire to reveal, in the public sphere, those dimensions that are not very visible, or rather to discuss certain issues of identity that those in authority fail to recognize" (Gardella; Monnet, 2006, p. 10). This path to engagement is connected to the relationship with alterity, with means of collaborating with others and with groups in a relationship of attachment and belonging. As Neuberger specifies:

The relationship of belonging is one of sharing, with other people, values, beliefs, goals, and interests that create a real or psychological community. Belonging requires an engagement with the group. One of the effects of this type of relationship is that it creates solidarity and loyalty amongst the members of a group. It is in the context of identity. The existence of each person is based on this dual network consisting of a network of relationships, over which a system of belonging is superimposed. On the one side is attachment and, on the other, engagement (Neuberger, 2012, p. 21).

Speaking out in the context of a drama program, self-expression and participation in dialogue, offer adolescents not only the chance to explore, but also to act and to engage in their social context while sharing their vision of the world. 


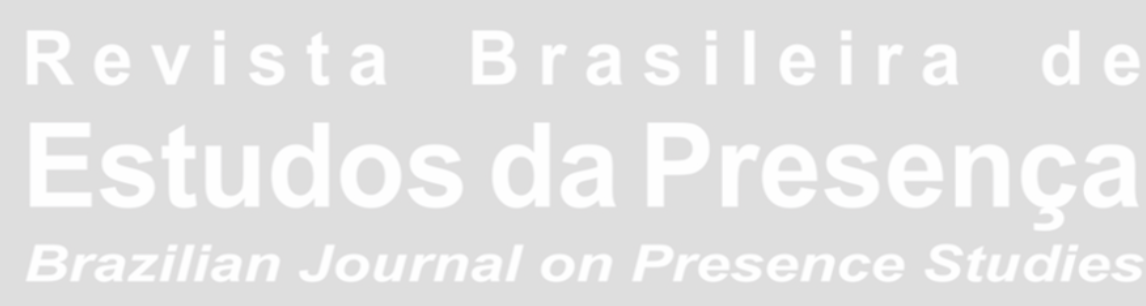

\section{Conclusion}

As we have just seen, both in Quebec at La Maison Jaune and in the francophone minority context at the Centre d'Excellence Artistique De La Salle, drama training offers a wealth of experiences that incite the adolescent to self-affirm and to engage with himself, with others and with art. Even if their linguistic context differs they both offer experiences in creation, performance, and art appreciation. These training programs help solidify the explicit links between the works of art created in a school setting and the personal and collective sense of accomplishment the students gain by creating and performing in these theatre productions. The training programs offer different gateways within an artistic lineage between professional artists and the next generation of artists who may eventually find themselves on the same stage. The role of aesthetic learning is considered as part of the training. Embodiment is also an important element in the developmental processes for these young students. Further research and observations are necessary to provide more details about this essential issue in Drama. These programs are of vital importance because they show young people the possibility of pursuing training and a career as a professional theatre artist. They also contribute to the development of young people's identity affirmation as they actively participate in both individual and collective artistic experiences. This participation is based on the presence of real dialogue between the group of students and the teacher, sharing moments of discovery and artistic creation and interpretation together. Dramatic art practice and the creative process can transform those who participate, and from this perspective create what we could call a pedagogy of transformation of people into characters and of the real into fiction (Baron Cohen, 2011, p. 88). Within the social context where these specialized drama training programs are established, they also serve as living proof of the vitality and even the survival of the culture. The uniqueness of the drama training offered at La Maison Jaune and at the Centre d'Excellence Artistique De La Salle shows us, as adults, the potential greatness of what adolescents have to say when they are given the opportunity to reach for their dreams. 


\section{Notes}

${ }^{1}$ In 2011, Quebec, a province with a francophone majority, was comprised of "7.8 million inhabitants: 78\% with French as their mother tongue, 7.6\% with English as their mother tongue, 12,3\% with other than English or French as their mother tongue (Allophones and Aboriginal)" (Leclerc, 2011, n.p.). In 2006, in Ontario, with a total population 12228 895, there were 582855 Francophones, representing $4.8 \%$ of the population in a geographical area superior to that of France and Spain combined (Office des Affaires Francophones de l'Ontario, 2006).

${ }^{2}$ Theatre Conservatory of Quebec, National Theatre School of Canada or St-Hyacinthe College.

${ }^{3}$ Department of Theatre of the Universite d'Ottawa.

\section{References}

ANADÓN, Marta. La Recherche Dite Qualitative: de la dynamique de son évolution aux acquis indéniables et aux questionnements présents. Recherche Qualitative, Trois-Rivières, v. 26, n. 1, p. 5-31, 2006. Available at: <http://www.recherche-qualitative.qc.ca/revue/>. Accessed on: 04 July 2014.

ANADÓN, Marta; GOHIER, Christiane. La Pensée Sociale et le Sujet: une réconciliation méthodologique. In: LEBRUN, Monique (Ed.). Les Représentations Sociales: des méthodes de recherche aux problèmes de société. Montréal: Logiques, 2001. P. 19-41.

ARDENNE, Paul; BEAUSSE, Pascal; GOUMARRE, Laurent. Pratiques Contemporaines: l'art comme expérience. Paris: Dis Voir, 1999.

BARON COHEN, Dan. Towards a Pedagogy of Transformation. In: SCHONMANN, Shifra. Key Concepts in Theatre/Drama Education. Rotterdam: Sense Publishers, 2011. P. 87-92.

BEAUCHEMIN, Esther. La Meute. Sudbury: Prise de Parole, 2005.

BUBER, Martin. Je et Tu. Paris: Aubier-Montaigne, 1969.

CHAÎNÉ, Francine. L'Observation d'un Processus de Création Théâtrale par les Adolescents et les Effets sur le Savoir Artistique: autoethnographie d'une recherche. Éducation et Francophonie, Québec, v. XL, n. 2, p. 69-82, 2012.

CONSEIL DE PLANIFICATION SOCIALE D'OTTAWA. Profil de la Communauté Francophone à Ottawa: selon le recensement de 2006. Ottawa, 2010. Available at: <http:// www.spcottawa.on.ca/sites/all/files/pdf/2010/Publications/Profil-Francophones.pdf >. Accessed on: 26 June 2014.

DEWEY, John. L'Art comme Expérience. Paris: Gallimard, 2005.

DEWEY, John. Experience \& Education. New York: Touchstone, 1997 [1938].

ÉCOLE SECONDAIRE CARDINAL-ROY. Sports-Arts-Études. Québec, 2011. Available at: <http://recitcscapitale.ca/cardinalroy/disciplines.php >. Accessed on: 25 July 2014. 
ÉCOLE SECONDAIRE PUBLIQUE DE LA SALLE. Centre d'Excellence Artistique. Ottawa: Conseil des Écoles Publiques de l'Est de l'Ontario, 2014. Available at: <http:// www.de-la-salle.cepeo.on.ca/programmes/centre-d-excellence-artistique>. Accessed on: 25 June 2014.

EISNER, Elliot W. What the Arts Teach and how it Shows. In: EISNER, Elliot W. The Arts and the Creation of Mind. New Haven: Yale University Press, 2002. P. 70-92.

FÉDÉRATION NATIONALE DES CONSEILS SCOLAIRES FRANCOPHONES. École Communautaire Citoyenne: un projet rassembleur par et pour la francophonie canadienne - document de fondements. Ottawa, oct. 2011.

FRAENKEL, Jack R.; WALLEN, Norman. How to Design and Evaluate Research in Education. 7. ed. Montreal: McGraw-Hill, 2009.

FREIRE, Paul. Pédagogie des Opprimés. Paris: Maspéro, 1974.

GAGNON, Steve. La Montagne Rouge (Sang). Moncton: Les Éditions de L'Instant Même, 2010.

GAGNON, Yves-Chantal. L'Étude de Cas comme Méthode de Recherche. 2. ed. Québec: Les Presses de l'Université du Québec, 2011.

GARDELLA, Édouard; MONET, Éric. Éditorial. Tracés: revue des sciences humaines, Lyon, v. 2, n. 11, p. 9-15, 2006. Available at: <http://traces.revues.org/358>. Accessed on: 03 July 2014.

GAUDREAU, Jean-Rock. Deux Pas sur les Étoiles. Carrières-Morlanwelz: Lansman Éditeur, 2008.

GOUVERNEMENT DU QUÉBEC. Ministère de l'Éducation, du Loisir et du Sport. Programme de Formation de l'École Québécoise: enseignement secondaire, deuxième cycle. Québec, 2006.

HAGEDORN, Robert. Current Perspectives in Sociological Research. In: HAGEDORN, Robert (Org.). Sociology. 2. ed. Toronto: Holt Rinehart, 1983. P. 11-19.

HAMEL, Jacques. Étude de Cas et Sciences Sociales. Paris: L'Harmattan, 1997.

HOYI, Yaovi. Projet d'École Communautaire Citoyenne: le Centre d'Excellence Artistique De La Salle - un centre artistique préprofessionnel pour jeunes francophones de la $7^{\mathrm{e}}$ à $12^{\mathrm{e}}$ année. Ottawa: Centre d'Excellence Artistique De La Salle/Conseil des Écoles Publiques de l'Est de l'Ontario, 2013.

HUOT, Marie-Eve. Nouds Papillon. Carrières-Morlanwelz: Lansman Éditeur, 2013.

KARSENTI, Thierry; SAVOIE-ZAJC, Lorraine (Eds.). La Recherche en Éducation: étapes et approches. 3. ed. St-Laurent: Erpi, 2011.

LECLERC, Jacques. Données Démolinguistiques. L’Aménagement Linguistique dans le Monde, Québec, 2011. Available at: <http://www.axl.cefan.ulaval.ca/amnord/Quebec2demo.htm\#1.2_Les_francophones_du_Québec>. Accessed on: 04 July 2014. 
LINTON, Ralph. Le Fondement Culturel de la Personnalité. Paris: Éditions Dunod, 1977.

MERRIAM, Sharan B. Case Study in Education: a qualitative approach. San Francisco: Jossey-Bass, 1988.

MINISTÈRE DE L'ÉDUCATION DE L'ONTARIO. Éducation Artistique: le curriculum de l'Ontario de la $1^{\text {ère }}$ à la $8^{\mathrm{e}}$ année. Toronto: Ministère de l'Éducation et de la Formation de l'Ontario, 2009. Available at: <http:/www.edu.gov.on.ca/fre/curriculum/elementary/ arts18b09currf.pdf $>$. Accessed on: 19 June 2014.

MINISTÈRE DE L'ÉDUCATION DE L'ONTARIO. Éducation Artistique: le curriculum de l'Ontario de la $9^{\mathrm{e}}$ et $10^{\mathrm{e}}$ année. Toronto: Ministère de l'Éducation et de la Formation de l'Ontario, 2010a. Available at: <http://www.edu.gov.on.ca/fre/curriculum/secondary/ arts910curr.pdf>. Accessed on: 18 June 2014.

MINISTÈRE DE L'ÉDUCATION DE L'ONTARIO. Éducation Artistique: le curriculum de l'Ontario de la $11^{\mathrm{e}}$ et $12^{\mathrm{e}}$ année. Toronto: Ministère de l'Éducation et de la Formation de l'Ontario, 2010b. Available at: <http://www.edu.gov.on.ca/fre/curriculum/secondary/ arts910curr.pdf $>$. Accessed on: 18 June 2014.

MOREAULT, Éric. La Montage Rouge (Sang): exorciser le démon du suicide. Le Soleil, Québec, 25 oct. 2010. Available at: <http://www.lapresse.ca/le-soleil/arts-et-spectacles/ theatre/201010/25/01-4335723-la-montagne-rouge-sang-exorciser-le-demon-du-suicide. php>. Accessed on: 25 June 2014.

MUCCHIELLI, Alex. Dictionnaire des Méthodes Qualitatives en Sciences Humaines. 3. ed. Paris: Armand Colin, 2009.

MUCCHIELLI, Alex. L'Identité. Paris: PUF, 1986.

NEELANDS, Jonothan. Acting Together: ensemble as a democratic process in art and life.

Research in Drama Education: the journal of applied theatre and performance, London, v. 14, n. 2, p. 173-189, 2009.

NEUBERGER, Robert. Exister: le plus intime et fragile des sentiments. Paris: Payot, 2012.

OFFICE DES AFFAIRES FRANCOPHONES DE L'ONTARIO. Portrait de la Communauté Francophone de l'Ontario. Toronto, 2006. Available at: <http://www.ofa. gov.on.ca/fr/franco.html>. Accessed on: 19 June 2014.

PAILLÉ, Pierre; MUCCHIELLI, Alex. L'Analyse Qualitative en Sciences Humaines et Sociales. 2. ed. Paris: Armand Colin, 2008.

PERREAULT, Marilyn. Les Apatrides. Saint-Laurent: Dramaturges, 2005.

PERREAULT, Marilyn. Britannicus Now. Carrières-Morlanwelz: Lansman, 2011.

POUPART, Jean. L'Entretien de Type Qualitatif: considérations épistémologiques, théoriques et méthodologiques. In: POUPART, Jean et al. (Eds.). La Recherche Qualitative: enjeux épistémologiques et méthodologiques. Montreal: Gaëtan Morin, 1997. P. 173-206.

SARTRE, Jean-Paul. Huis Clos/Les Mouches. Paris: Gallimard, 1972. (Collection Folio.) 


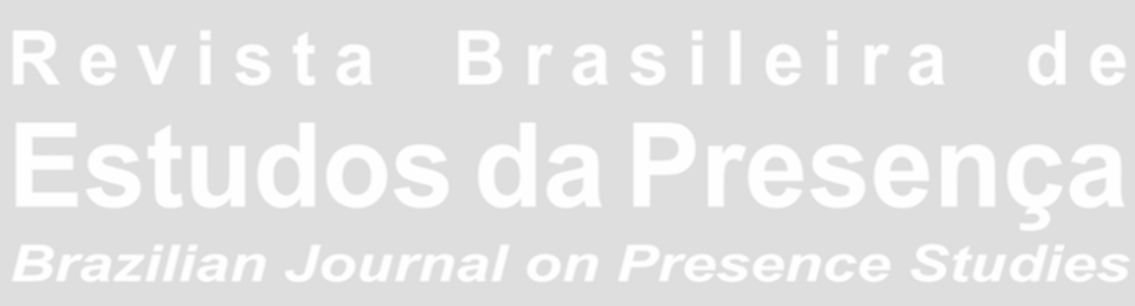

E-ISSN 2237-2661

SAVOIE-ZAJC, Lorraine. La Recherche Qualitative/Interprétative en Éducation. In: KARSENTI, Thierry; SAVOIE-ZAJC, Lorraine (Eds.). Introduction à la Recherche en Éducation. Sherbrooke: Éditions du CRP, 2000. P. 171-198.

SCHÖN, Donald A. The Reflective Practitioner. New York: Basic Books, 1983.

SEARS ONTARIO DRAMA FESTIVAL. Provincial Showcase Awards 2014. Hamilton, 2014. Available at: <http://www.searsdramafestival.com/2014_Awards/ProShow.htm>. Accessed on: 20 June 2014.

SÉVIGNY, Robert. Expérience. In: BARUS-MICHEL, Jacqueline; ENRIQUEZ, Eugène; LÉVY, André (Eds.). Vocabulaire de Psychosociologie: références et positions. Ramonville-Saint-Agne: Érès, 2003. P. 128-133.

TABLE NATIONALE SUR L'ÉDUCATION. L'École Communautaire Citoyenne: cadre de référence - pour l'émergence de l'école communautaire citoyenne au sein des communautés francophones et acadiennes du Canada. Ottawa: Centre Franco-Ontarien de Ressources Pédagogiques, 2012. Available at: <http://www.fncsf.ca/files/ECC_cadre_ reference_final\%2811\%29.pdf>. Accessed on: 02 July 2014.

THÉBERGE, Mariette. On Being and Becoming a Secondary School Drama/Theatre Teacher in a Linguistic Minority Context. Theatre Research in Canada/Recherches Théâtrales du Canada, Toronto, v. 28, n. 2, p. 67-78, 2007.

Francine Chaîné is a professor in the department of visual art at the Université Laval, where she directs, and teaches in, the undergraduate art education program. She holds a MA Master in Visual Arts from the Université du Québec à Montréal (UQAM) and a PhD in Drama Education from the Université de Montreal.

E-mail: francine.chaine@arv.ulaval.ca

Mariette Théberge is a professor of Arts Education in the faculty of education at the Université d'Ottawa. She studied Drama in Paris and holds a Bachelor of Music in Education from Université du Québec à Montréal (UQAM), a Master of Education from the Université d'Ottawa, and a PhD in Education from UQAM.

E-mail:mtheberg@uottawa.ca

This unpublished text, translated from French by Jennifer Boyes-Manseau and proofread by Ananyr Porto Fajardo, is also published in Portuguese in this issue.

Received in July 11, 2014 Accepted in December 2, 2014 